\title{
Relevance of Accounting Information by Measuring the Predictability of Chosen Accounting Items of Manufacturing Firms Listed in Borsa Istanbul (BIST)
}

\author{
Dr. Mohammed ALAshi \\ Asst. Prof. of Accounting and Finance \\ Accounting Department, College of Commerce \\ The Islamic University, Gaza - State of Palestine
}

\begin{abstract}
Based on the importance of accounting information quality, this study attempts to measure the information predictability of manufacturing firms listed in Borsa Istanbul. To accomplish its objectives, the study measures the predictability of some chosen accounting elements through applying the ARIMA model. According to the results of applying the ARIMA model on the chosen accounting elements, it is concluded that 14 and 20 firms had their predictability increase for Inventory and Accounts receivable elements respectively after the adoption of IFRS. When these results are examined for significance using the Proportional test, the predictability of Inventory and Accounts receivable elements is deemed significant. In addition, the MAPE of the model's ability of estimation show that the accuracy of estimation either decreased or stayed the same after the adoption of IFRS.
\end{abstract}

Keywords: IFRS, Predictability, Relevance, Borsa Istanbul.

\section{Introduction}

In the business world, there is a joint mother tongue between business firms. In spite of firms' goals, each firm has decision makers, external and internal, who need information to make decisions. The main kind of needed information is accounting information. Generally, the accounting information is presented by financial reports. Concisely, accounting information plays a vital role in the decision making process at organizations (Corina \& Nicolae, 2012; Gafarov, 2009; Stvilia, Gasser, Twidale, \& Smith, 2007). Accounting information is also important to equity investing decisions, as well as to contracting decisions (Barth, Beaver, \& Landsman, 2001).

The accounting information should be characterized by relevance and faithfulness. Information to be relevant, it should have three sub characteristics; predictive value, confirmatory value, and materiality. In order to be faithfully represented, information should be complete, neutral and free from error (International Accounting Standards Board, 2010; Kieso, Weygandt, \& Warfield, 2012).

In the last decade there were a lot of debates between related bodies in the different countries. These debates escalated from debating harmonization levels to debating uniform levels of the accounting standards. In 2005, all European countries started to adopt the IASB's standards (The IFRS Foundation and the IASB, 2013). In addition, the Turkish Capital Markets Board issued a bulletin requiring all listed firms

\footnotetext{
* This article was submitted in May 2017, and accepted for publishing in July 2017, Published: June 2020.

(C) Arab Administrative Development Organization- League of Arab States, 2020, pp 247-266، DOI: 10.21608/aja.2020.88337
} 
to prepare their financial statements in accordance with IFRS starting from 1 January 2005. Even though, some of the firms started the adoption of IFRS in 2003 (Bahadir \& Tolga, 2013; Pekdemir \& Türel, 2014).

\section{Information quality}

Upon to IASB, information quality is characterized as the following:

1- Relevance: «Volatility of information is a measure of information instability. The frequency of change of the value for an entity is an attribute of interest (the «source value»). The more volatile information is, the more rapidly any recorded value becomes less relevant. Nonvolatile information is stable; it does not change or become dated.» (Bovee, Srivastava, \& Mak, 2003). And according to the conceptual framework of IASB, «Relevant financial information is capable of making a difference in the decisions made by users. Financial information is capable of making a difference in decisions if it has predictive value, confirmatory value or both, and materiality.

a- Financial information has predictive value if it can be used as an input to processes employed by users to predict future outcomes.

b- Financial information has confirmatory value if it provides feedback about (confirms or changes) previous evaluations.

c- Materiality: Information is material if omitting it or misstating it could influence decisions that users make on the basis of financial information about a specific reporting entity. »

2- Faithful representation: To be a perfectly faithful representation, a depiction would have three characteristics. It would be complete, neutral and free from error.

a- A complete depiction includes all information necessary for a user to understand the phenomenon being depicted, including all necessary descriptions and explanations.

b- A neutral depiction is without bias in the selection or presentation of financial information.

c- Free from error means there are no errors or omissions in the description of the phenomenon.

\section{Measuring quality of accounting information}

Mainly, measuring the quality of accounting information has two attributes (1) accounting-based and (2) market-based. The accounting-based attribute includes features of accounting numbers which are influenced only by the recognition and measurement principles. It includes accruals' quality, persistence of earnings, predictability of earnings, and smoothness of earnings. The accounting-based attribute does not refer to market value. The market-based attribute, on the other hand, reflects economic income as represented by market returns, and it includes the value relevance of accounting numbers, timeliness, and conservatism.

The following section presents a brief literature about each attribute:

\section{Accruals quality}

Revenues and expenses presented in income statements consist of cash and accrual components. When earnings are closer to cash flow or when earnings has larger cash components, then earnings is of higher quality (Francis, LaFond, Olsson, \& Schipper, 2005). The accruals are divided into discretionary and nondiscretionary accruals. Discretionary accruals create noise that affects earnings; it does not add valuable information to earnings and could be manipulated, hence decline earnings quality (Dechow \& Dichev, 2002). 


\section{Persistence and predictability of earnings}

The persistence of earnings is concerned with its variability. It is measured as the slope coefficient in a regression of current earnings on lagged earnings (Francis, LaFond, Olsson, \& Schipper, 2004; Lev, 1983). Precisely, it is the quality of information that helps decision makers increase the probability of correctly forecasting the outcome of past or present events (Herrmann, Saudagaran, \& Thomas, 2006).

\section{Smoothness of earnings}

A form of earnings management designed to remove the peaks and valleys of earnings, hereafter reducing the volatility, from a normal earnings series, to deliver an impression of more stability (Mulford, 2002). Managers smooth earnings by varying the application of accounting standards or by influencing operating, financing, and investment decisions. The measure of earnings smoothness is a measure of the volatility of earnings relative to a benchmark (Francis et al., 2004).

\section{Value relevance}

The value relevance of financial information is the ability of financial data to summarize a firm's value or to reflect information that affects stock market measures, stock returns, and stock turnover (Fiador, 2013). Or by other words, measuring the significance of the relationship between the market value and the accounting numbers of a firm.

Value relevance has four interpretations; «(1) financial statement information leads stock prices by capturing intrinsic share values toward which stock prices drift. (2) financial information is value relevant if it contains the variables used in a valuation model or assists in predicting those variables. (3) the ability of financial statement information to change the total mix of information in the marketplace. (4) the ability of financial statement information to capture or summarize information.» (Francis \& Schipper, 1999).

But the achievement of high quality of information is somehow difficult because; (1) of its complexity and multidimensionality; (2) it is affected by the economic environment which is out of the control of standard setters; (3) some tradeoffs might be necessary for the political process (Ely \& Waymire, 1999).

Historically, there were many studies during the seventieth and eightieth decades that studied the relevancy of accounting information. Some event studies examine the change in share price to measure the impact of the signaling of financial statements (Ball \& Brown, 1968; Beaver, 1968). And in the beginning of ninetieth decade, researchers evaluated relevancy through measuring the relationship between market return and accounting earnings (Easton \& Harris, 1991; Lev, 1989).

Currently, there are many studies that measure the relevancy in different countries. They conclude that significant differences among the countries and accounting rules exist. Value relevance is subject to changes upon to the actions of standard setters and upon to the changes in the economic and social environment. There is an important transference in the research topic orientation from evaluating exclusively the existence of information content of accounting numbers towards investigating the interplay of accounting environment and the institutional and economic background of financial reporting. (Alford, Jones, Leftwich, \& Zmijewski, 1993; Bao \& Chow, 1999; Harris, Lang, \& Möller, 1994; Joos \& Lang, 1994) 
External factors has the ability to influence the relevancy of accounting information (Holthausen \& Watts, 2001). This idea directed researchers to measure the impact of external factors; such as how institutional alterations among different countries influence properties of firms (Ball, Kothari, \& Robin, 2000). Some factors were found to impact the relevance of accounting information; for instance, bank-versus market orientation of financial systems, the involvement of private sector bodies in standard setting, code law versus common law based accounting regimes, tax influence on financial accounting, and external auditing expenditures (Ali \& Hwang, 2000). The relevance of accounting information is measured better by giving a substantial weight to the institutional influences on actual reporting incentives of the preparers, and not to focus the measurement on classifying countries and evaluating the value relevance of accounting information in terms of formal accounting standards (Ball, Robin \& Wu, 2003).

\section{Timeliness}

Timeliness is one of the accounting information characteristics in the IASB's conceptual framework (International Accounting Standards Board, 2010). Timeliness of accounting information includes both frequency of accounting information and the speed with which accounting information is published (Barth et al., 2001). It is understood as the ability to communicate information to decision makers before it losses capacity to influence decisions (Herrmann et al., 2006).

\section{Conservatism}

It is known as accelerating the recognition of economic losses and deferring the recognition of economic gains (S. Basu, 1997). Accounting conservatism is defined as the magnitude of the coefficients on earnings and book value of equity in a price regression (Harris et al., 1994). In addition, accounting is defined as conservatism if it recognizes losses faster than gains (Basu \& Wang, 2011).

\section{Literature review}

There are many studies that discuss the accounting information quality; a lot of these studies measure the quality by comparing information quality before and after adopting IFRS, or by comparing listed firms that adopt IFRS and listed firms that adopt US GAAP, or by comparing firms in different countries. (Jeanjean \& Stolowy, 2008) measure the quality of earnings post of the adoption of IFRS at different countries (Australia, France, and United Kingdom) through analyzing the discontinuities in the distribution of earnings before and after applying the IFRS. (Barth, Landsman, Lang, \& Williams, 2006) measure the accounting quality by making a comparison between firms that apply US GAAP in the USA and firms that apply IAS in France and Germany. (Djatej, Gao, Sarikas, \& Senteney, 2011) find the differences between information quality in western European and eastern European firms. (Alali \& Foote, 2012) measure the relevance of accounting information for firms listed and traded in Abu Dhabi Securities Exchange. (Haller, Ernstberger, \& Froschhammer, 2009) compare between equity and net income at German firms before and after adopting IAS 11, IAS 16, IAS 37, IAS 38 and IFRS 3. (Chen, Tang, Jiang, \& Lin, 2010) measure the impact of adopting IFRS at firms located in 15 states of the European Union. (Ashbaugh \& Pincus, 2001) measure the impact of adopting IAS in comparison to domestic standards to find the negative affect of inaccurate earnings forecast. (Okafor, Anderson, \& Warsame, 2016) measure the impact of adopting IFRS in comparison to Canadian 
GAAP. (Joshi, Yapa, \& Kraal, 2016) measure the perception of professional accountants in Singapore, Malaysia, and Indonesia aiming to evaluate their supposed benefit. (Ebaid, 2016) evaluate the earnings management before and after the adoption of IFRS. (Mostafa, 2016) evaluate the impact of IFRS by measuring the value relevance before and after adopting IFRS for the Egyptian listed companies.

Most of the published studies measure the accounting information quality by similar approaches; through measuring earnings management, income smoothing, and timely loss recognition. (Barth et al., 2006) examine accounting information quality by measuring (1) variability of change in net income, (2) variability of change in net income relatively to change in cash flow. While as (Alali \& Foote, 2012) examine the (1) variability of change in net income, (2) variability of change in net income relatively to change in cash flow. (Haller et al., 2009) use the index of comparability to find the differences between equity and net income before and after adopting IFRS. (Chen et al., 2010) measure the impact of IFRS using five factors; earnings smoothing, managing earnings toward targets, the magnitude of absolute discretionary accruals, accruals quality, and timely loss recognition. (Paananen \& Lin, 2007) measure earnings smoothing and timely loss recognition by creating a regression model with multiple factors such as; liabilities to assets, change in sales, ...etc. (Karampinis \& Hevas, 2011) measure value relevance by finding the relationship between accounting figures, market returns and prices, and asymmetric recognition of economic losses and gains. (Anandarajan \& Hasan, 2010) measure the association of earnings and change in earnings with equity values. In addition, (Rahman, Yammeesri, \& Perera, 2010) examine information quality by finding the relationship between the abnormal accruals of accounting earnings and independent variables such as; equity, long term debt, short term debt, market return, market value, and growth. (Clarkson, Hanna, Richardson, \& Thompson, 2011) measure the relevance of book value and earnings for the level of stock price.

Most studies have different methodologies to measure accounting information quality. (Kohlbeck \& Warfield, 2010) follow three different methodologies to find the relationship between standards and information quality; (1) a comparison between unexplained changings in net income before and after implementing the standards, (2) a measurement of the correlation between cash flow and accruals; according to the assumption that firms managing earnings will have a negative relationship between cash flow and accruals. (3) also a measurement of the correlation between cash flow and accruals after controlling for firm size, growth, equity issues, leverage, debt issues, sales turnover, and the presence of a Big $\mathrm{N}$ auditor. (Dechow, 1994) measures the relationship between earnings and stock return, and between cash flow and stock return in short intervals through analyzing the regression between earnings and stock return, cash flow and stock return, and cash flow from operating activities and stock return. (Rahman et al., 2010) differentiate between different accounting information qualities according to different influence theories in the country, by observing the agency theory in US firms, high block holder concentration in French firms, and family owned businesses in Thailand. (Okafor et al., 2016) find the adjusted R square of regression model of stock price on book value and earnings. (Joshi et al., 2016) use survey to find professional accountants perceptions in the three countries of the study. (Ebaid, 2016) find the earnings management through measure the income smoothing by the variability of the change in net income scaled by total assets. (Mostafa, 2016) examine the association between earnings and book value of equity, and stock price.

On the other hand, studies examine the quality of accounting information using different periods and different number of observations. (Kohlbeck \& Warfield, 2010) study quality according to the available data 
between 1976 and 2005; with 91,931 observations. (Dechow, 1994) studies a sample which consists of the listed firms in NYSE and ASE with three intervals; quarterly, annually, and of four years. (Jeanjean \& Stolowy, 2008) study 1146 firms; 422 in Australia, 321 in France, 403 in United Kingdom, excluding insurance and investment firms as they have specific accounts structure. (Barth et al., 2006) study the non US firms that apply IAS and US firms that apply US GAAP, by matching these two groups after classifying them based on (1) common period, (2) size; based on equity value, and (3) activity of the firms. (Djatej et al., 2011) divide the sample into 4892 firms from western Europe, and 1852 firms from eastern Europe. (Alali \& Foote, 2012) use the data of listed firms between 2000 and 2006. (Haller et al., 2009) use the information of listed firms in the official and regulated market in Germany. (Chen et al., 2010) use data from listed firms from 15 different states of the European Union between 2000 and 2007. (Paananen \& Lin, 2007) use the information of industrial listed firms found in the Data Stream database through 2000 to 2006. (Karampinis \& Hevas, 2011) use the information of listed firms in Athens Stock Exchange from 2002 to 2007, by dividing the period into two parts; before adopting IFRS from 2002 to 2004 and after adopting IFRS from 2005 to 2007. (Barth et al., 2008) use the information of listed firms in 21 countries which adopted IAS between 1994 and 2003.

Several studies examine the quality of accounting information across different countries. (Barth et al., 2006) states that US firms have more variances for the change in income and the change in cash flow than non US firms, and the correlation between accruals and cash is significantly less negative in the US firms compared with non US firms. Generally, US firms that apply US GAAP have more information quality than non US firms. (Djatej et al., 2011) find that the quality of public and private information in western European countries is higher than the quality of public and private information in eastern European countries. (Anandarajan \& Hasan, 2010) find that the relevance of information is affected by the level of mandated disclosure, the source of standards in the different countries, in addition, the legal environment.

By looking at the results of different studies, most agree that the adoption of IFRS improve the information quality when compared with local standards. (Alali \& Foote, 2012) state that adopting IFRS increases the relevance of accounting information, which is more relevant for small firms than big firms. (Haller et al., 2009) state that IAS 16, IAS 19, IAS 37 and IFRS 3 have significant effect on equity post adoption of IFRS. (Chen et al., 2010) find that adopting IFRS improve accounting information quality by reducing the targeted earnings management, as adopting IFRS increases accrual quality. (Barth et al., 2008) state that adopting IAS declines earnings management and improves the quality of time for loss recognition, which means that IAS improves information quality. (Ashbaugh \& Pincus, 2001) find that, after adopting IAS, earnings forecasts have been improved.

On the contrary, some studies find that adopting IFRS increases earnings management. (Paananen \& Lin, 2007) state that the adoption of IFRS has a negative effect on accounting information quality because of the conversion into the new standards. (Karampinis \& Hevas, 2011) find that adopting IFRS has minor impact on information quality, while (Clarkson et al., 2011) find that the benefit of adopting IFRS is limited. (Jeanjean \& Stolowy, 2008) state that earnings management does not decline after adopting IFRS, but it even increases in France after the adoption.

\section{Contribution of this study}

According to the previous literature review, accounting information quality is measured based on aggregated amounts extracted from financial statements; such as Net Income and Owners' Equity amounts. They measure the quality of accounting information through the measurement of earnings management, 
income smoothing, and timely loss recognition (Ballou \& Pazer, 1985; Barth et al., 2006; Bovee et al., 2003; Dechow, 1994; Eppler \& Wittig, 2000).

To my best knowledge, no study has applied a methodology that measures the quality of accounting elements, such as; Inventory, Accounts receivable, Accounts payable...etc.

According to one of Francis and Schipper interpretations of value relevance that « financial information is value relevant if it contains the variables used in a valuation model or assists in predicting those variables» (Francis \& Schipper, 1999) and IASB's concept of predictability that «Financial information has predictive value if it can be used as an input to processes employed by users to predict future outcomes.»(International Accounting Standards Board, 2010), the main contribution of this study is measuring the quality of Inventory, and Accounts receivable, as separate accounting elements through measuring their predictability.

\section{Importance of the chosen accounting elements}

This study evaluates the predictability Inventory and Accounts receivable. The choosing of these elements is justified as follows:

\section{Inventory}

The different accounting procedures of financial reporting are important to different categories of decision makers, such as; financial accounting policy makers, firms' managers, and investors (Sunder, 1973). Inventory could be evaluated through the use of different accounting methods. This diversity of accounting procedures provides managers with opportunities to manipulate inventory, which in turn, could lead to a significant manipulation of earnings and taxes. The way that inventory is managed has a significant impact on the profitability of the firm (Ashraf, 2012) and its manipulation could also cause a change in a firm's cash flow (Biddle, 1980, 1988; Olsson, 2008). Maximizing the profitability of firms could also be done by applying different ways of managing cash conversion cycles, which include the inventory cycle (Lazaridis \& Tryfonidis, 2006). In addition, by changing the production level, firms can manipulate the amount of earnings (Cook, Huston, \& Kinney, 2011; Gupta, Pevzner, \& Seethamraju, 2010). Furthermore, changes in inventory is a significant predictor of future earnings (Thomas \& Zhang, 2002; Weiss, Naik, \& Tsai, 2008).

Besides that, manipulating fixed costs allocations could allow the manipulation of earnings (Cook et al., 2011). Firms with high levels of fixed costs can manipulate their income and increase their return on assets which, in turn, impacts the stock return in the future (Gupta et al., 2010). Furthermore, inventory cost flow methods applied by firms affect their level of information risk (Krishnan, Srinidhi, \& Su, 2008) and their level of cost of capital (Fields et al., 2001).

Specific choices of inventory policies provide information with incremental value to investors (Olsson, 2008). In addition, the applied inventory policy signals some information quality characteristics that is used in valuing firms (Krishnan et al., 2008). In another line, the changes in accounting choices cause abnormal working capital accruals (DeFond \& Jiambalvo, 1994). An increasing amount of inventory reflects difficulties in creating sales, which in turn, affects stock return (N. Basu \& Wang, 2011). In addition, inventory has a potential signal into market value (Lai, 2006). 


\section{Accounts receivable}

Trading in credit is a vital tool in financing firms (Bougheas, Mateut, \& Mizen, 2009). In the ninetieth decade, the amount of trade credit in all American firms was 17.8 percent of total assets. In Germany, France, and Italy it was more than 25 percent of total assets (Rajan \& Zingales, 1995). Trading in credit is important in emerging markets especially when firms get limited credit from the banking systems (Ge \& Qiu, 2007).

There is a significant relationship between the cash conversion cycle; which includes the accounts receivable cycle, and the profitability of a firm (Lazaridis \& Tryfonidis, 2006). The way that accounts receivable is managed will have a significant impact on a firm's profitability (Ashraf, 2012). Firms with poor quality of accounts receivable information has credit risk exposure (Sopranzetti, 1998). Some researchers prove that a negative relationship between accounts receivable and firms' profitability exists (Ashraf, 2012; Lazaridis \& Tryfonidis, 2006; Wongthatsanekorn, 2010). Several factors could impact the predictability of accounts receivable such as; the size of customers and sales distributed to them (Mao \& Sarndal, 1974).

\section{Study objectives}

This study aims to fulfill the following goals:

1- Attest whether Inventory predictability improves after the adoption of IFRS at the manufacturing firms listed in Borsa Istanbul.

2- Attest whether Accounts receivable predictability improves after the adoption of IFRS at the manufacturing firms listed in Borsa Istanbul.

\section{Study hypothesis}

Upon to IASB, accounting information should be relevant to make decisions. Information to be relevant, it should have three sub characteristics; predictive value, confirmatory value, and materiality. Financial information has predictive value if it can be used as an input to processes employed by users to predict future outcomes. (International Accounting Standards Board, 2010). Therefore, this study tests the following hypotheses to detect the predictability of Inventory and Accounts receivable.

\section{Inventory}

Successive adoption of IFRS, higher accounting information predictability of inventory at the manufacturing sector by measuring the predictability of its time series for each firm for the pre and post IFRS adoption periods.

\section{Accounts receivable}

Successive adoption of IFRS, higher accounting information predictability of Accounts receivable at the manufacturing sector by measuring the predictability of its time series for each firm for the pre and post IFRS adoption periods.

\section{Data and sample selection}

The data used in the empirical part of this study is divided into two periods. The first period is between 1996 and 2004, while the second period is between 2005 and 2013. Numerous databases are used to 
construct the dataset. The databases of the public disclosure platform (KAP) and Borsa Istanbul (BIST) are utilized for extracting the market share of listed manufacturing firms. Additionally, the database of FINNET is used to extract the data of financial statements of the manufacturing listed firms. The sample is comprised of all manufacturing listed firms on BIST for an 18 year observation period. However, firms that lack consecutive data are eliminated to construct a balanced pooled data model. Furthermore, firms which lack data for the chosen accounting elements between 1996 and 2013 are also eliminated. In addition, to achieve a balanced pooled data between 1996 and 2013, firms which lack data for the dependent and independent variables are eliminated.

The total number of manufacturing listed firms for the period 1996 - 2013 at Borsa Istanbul is 161 firms. The firms that fulfill the sample selection criteria, classified for each chosen accounting element, are summarized as follows; 102 firms selected to examine the relevancy of Inventory and 98 firms selected to examine the relevancy of Accounts receivable.

\section{Methodology: Predictability of the chosen accounting elements, examined by time-series (ARIMA)}

One of the main two characteristics of accounting information is relevancy, which has three sub characteristics; predictive value, confirmatory value, and materiality. Information has predictive value when it can be used to make predictions (International Accounting Standards Board, 2010). Upon to this definition, this part examines whether the chosen accounting elements could be used statistically to make predictions. To apply this concept, the Random Walk model is applied. It measures whether data has a stationary amount of change between each two consecutive observations (Klafter \& Sokolov, 2011; Lawler, 2010; Quantitative Micro Software (Firm), 2009; Rudnick \& Gaspari, 2004). Or more precisely, it determines whether information could be used to make predictions (Ostasiewicz, 2000; Quantitative Micro Software (Firm), 2009).

«It is surprising that so little work has been done on forecasting count data» (De Gooijer \& Hyndman, 2006). Count data is quantitative data such as; amount of inventory, accounts receivable... etc. There are many statistical models that can be used to measure the predictability of information such as; Dicky Fuller test, Phillips-Perron test, KPSS test, variance ratio test, and ARIMA model; which is based on Box-Jenkins approach. «The Box-Jenkins approach is a coherent, versatile, three stage iterative cycle for time series identification, estimation, and diagnostic checking. The evolution of computers made the use of autoregressive integrated moving average (ARIMA) models popular and applicable in many scientific fields.» (Christodoulos, Michalakelis, \& Varoutas, 2010; Ho \& Xie, 1998)

The Box-Jenkins approach is one of the most powerful forecasting techniques available and it can be used to analyze almost any set of data. It is expressed through the development of an ARIMA model, which is a generalization of an ARMA model. These models are fitted to time-series data in order to predict future points in the series. The model is generally referred to as an ARIMA $(p, d, q)$ model where $p, d$ and $q$ are integers, greater than or equal to zero and refer to the order of the autoregressive, integrated and moving average parts of the model, respectively. Given a time series of data Xt; where $t$ is an integer index and Xt are real numbers, corresponding to values at time $t$, then an ARIMA $(p, d, q)$ model is described by: 


$$
Y_{t}=\alpha+\phi_{1} Y_{t-1}+\phi_{2} Y_{t-2}+\cdots+\phi_{p} Y_{t-p}+\theta_{1} \varepsilon_{t-1}+\theta_{2} \varepsilon_{t-2}+\cdots+\theta_{q} \varepsilon_{t-q}
$$

AR stands for «autoregressive» and describes a stochastic process that can be described by a weighted sum of its previous values and a white noise error, while MA stands for «moving average» and describes a stochastic process that can be described by a weighted sum of a white noise error and the white noise error from previous periods (Christodoulos et al., 2010)

$\mathrm{Y}_{\mathrm{t}}$ is the actual value and $\varepsilon_{\mathrm{t}}$ is the random error at time $\mathrm{t}, \phi_{\mathrm{I}}$ and $\theta_{\mathrm{I}}$ are the coefficients, $\mathrm{p}$ and $\mathrm{q}$ are integers that are often referred to as autoregressive and moving average polynomials, respectively. Basically, this method has three phases: model identification, parameter estimation and diagnostic checking (Pai \& Lin, 2005).

Many studies use the ARIMA model for forecasting, for instance; (Ediger \& Akar, 2007) use it to forecast energy use in Turkey, (Pai \& Lin, 2005) use it to forecast stock prices, (Zhang, 2003) use it to forecast British pound / US dollar exchange rate, while as (Kumar \& De Ridder, 2010) use it to forecast daily maximum $\mathrm{O}_{3}$ concentrations and make probabilistic forecasts of ozone episodes.

In the empirical part of this study, ARIMA model is applied to measure whether the chosen accounting elements follow a random walk, to inspect the predictability of information.

\section{Data analysis and result}

The predictability of the chosen accounting elements is measured through applying the ARIMA model by examining whether the data could be used to make future predictions. The ARIMA model results, as mentioned earlier, could be described by $(p, d, q)$. «p» represents the autoregressive part, while «q» represents the moving average part of the results. If either of these parts is presented by the value of 1 , then the model could be used to make predictions. On the other hand, if both of these parts are presented by the value of 0 , then the model could not be used to make predictions. The results of each chosen accounting element are discussed separately as follows.

The ARIMA model is measured using SPSS package through applying Expert modeler function which automatically identifies and estimates the best-fitting ARIMA or exponential smoothing model for one or more target variables, thus eliminating the need to identify an appropriate model through trial and error. In all cases, the Expert Modeler picks the best model for each of the target variables specified.

\section{Measuring predictability of inventory}

The results of the ARIMA model, in regard to inventory information, is shown in the following table; (1) is used to present firms with predictable Inventory information, while (0) is used to present firms with no predictable Inventory information.

The Inventory data series consist of 102 firms with complete data for analysis. In the pre adoption period, 66.66 percent of the total sample of firms has Inventory information that could not be used to make future predictions. While as, 33.33 percent of the total firms has Inventory information that could be used to make future predictions. On the other hand, the post adoption period results show that the percentage 
number of firms with Inventory information that could be used to make future predictions increases to 47.05 percent, leaving 52.94 percent of total firms without an ability to predict future Inventory information. According to the results, 14 firms are shown to have gained an ability to predict Inventory information after the adoption of IFRS. This number could be explained as follows; 13 firms lost their predictability while 27 firms gained predictability after the adoption of IFRS, as shown in the following table.

Table 1: ARIMA Model (Inventory)

\begin{tabular}{|r|l|l|l|l|l|}
\hline \multirow{2}{*}{$\#$} & \multirow{2}{*}{ Firm } & \multicolumn{2}{|c|}{$\mathbf{1 9 9 6 -}$} & \multicolumn{2}{|c|}{$\mathbf{2 0 0 5 -}$} \\
\cline { 3 - 6 } & & Model & c & Model & c \\
\hline 1 & ADANA & $(0,1,0)$ & 0 & $(0,1,0)$ & 0 \\
\hline 2 & ADBGR & $(0,1,0)$ & 0 & $(0,1,0)$ & 0 \\
\hline 3 & ADEL & $(0,1,0)$ & 0 & $(2,1,0)$ & 1 \\
\hline 4 & ADNAC & $(0,1,0)$ & 0 & $(0,1,0)$ & 0 \\
\hline 5 & AFYON & $(3,1,0)$ & 1 & $(1,0,0)$ & 1 \\
\hline 6 & AKCNS & $(2,1,0)$ & 1 & $(1,1,1)$ & 1 \\
\hline 7 & AKSA & $(0,1,0)$ & 0 & $(0,1,0)$ & 0 \\
\hline 8 & ALCAR & $(4,1,0)$ & 1 & $(0,1,0)$ & 0 \\
\hline 9 & ANACM & $(4,1,0)$ & 1 & $(0,1,0)$ & 0 \\
\hline 10 & ARCLK & $(2,1,0)$ & 1 & $(0,1,0)$ & 0 \\
\hline 11 & ASLAN & $(3,1,0)$ & 1 & $(0,0,1)$ & 1 \\
\hline 12 & ASUZU & $(0,1,0)$ & 0 & $(1,1,0)$ & 1 \\
\hline 13 & ATEKS & $(0,2,0)$ & 1 & $(1,0,0)$ & 1 \\
\hline 14 & AYGAZ & $(0,1,0)$ & 0 & $(1,1,0)$ & 1 \\
\hline 15 & BAGFS & $(0,1,0)$ & 0 & $(1,0,0)$ & 1 \\
\hline 16 & BANVT & $(0,1,0)$ & 0 & $(0,1,0)$ & 0 \\
\hline 17 & BFREN & $(0,1,0)$ & 0 & $(0,1,0)$ & 0 \\
\hline 18 & BOLUC & $(2,1,0)$ & 1 & $(0,0,1)$ & 1 \\
\hline 19 & BOSSA & $(0,1,0)$ & 0 & $(0,1,0)$ & 0 \\
\hline 20 & BRISA & $(0,1,0)$ & 0 & $(0,1,0)$ & 0 \\
\hline 21 & BRSAN & $(0,1,0)$ & 0 & $(0,1,0)$ & 0 \\
\hline 22 & BTCIM & $(0,1,0)$ & 0 & $(0,1,0)$ & 0 \\
\hline 23 & BUCIM & $(0,1,0)$ & 0 & $(0,1,0)$ & 0 \\
\hline 24 & BURCE & $(0,1,0)$ & 0 & $(2,0,0)$ & 1 \\
\hline 25 & CELHA & $(1,1,0)$ & 1 & $(1,0,0)$ & 1 \\
\hline 26 & CEMTS & $(0,1,1)$ & 1 & $(1,0,0)$ & 1 \\
\hline 27 & CIMSA & $(0,1,0)$ & 0 & $(0,1,0)$ & 0 \\
\hline 28 & CMENT & $(0,1,0)$ & 0 & $(0,1,4)$ & 1 \\
\hline 29 & COMDO & $(0,2,1)$ & 1 & $(0,1,0)$ & 0 \\
\hline 30 & DARDL & $(1,1,0)$ & 1 & $(1,0,0)$ & 1 \\
\hline 31 & DENCM & $(0,1,0)$ & 0 & $(0,1,0)$ & 0 \\
\hline 32 & DERIM & $(0,1,0)$ & 0 & $(0,0,0)$ & 1 \\
\hline 33 & DEVA & $(0,1,0)$ & 0 & $(0,1,0)$ & 0 \\
\hline 34 & DGKLB & $(0,1,0)$ & 0 & $(0,1,0)$ & 0 \\
\hline
\end{tabular}

\begin{tabular}{|l|l|c|c|c|c|}
\hline \multirow{2}{*}{$\#$} & \multirow{2}{*}{ Firm } & \multicolumn{1}{|c|}{$\mathbf{9 9 6}-$} & \multicolumn{2}{|c|}{$\mathbf{2 0 0 5}-$} \\
\cline { 3 - 6 } & & Model & c & Model & c \\
\hline 35 & DGZTE & $(0,1,0)$ & 0 & $(0,1,0)$ & 0 \\
\hline 36 & DITAS & $(0,1,0)$ & 0 & $(0,1,0)$ & 0 \\
\hline 37 & DOGUB & $(0,1,0)$ & 0 & $(2,1,0)$ & 1 \\
\hline 38 & DURDO & $(0,1,0)$ & 0 & $(2,1,0)$ & 1 \\
\hline 39 & DYOBY & $(0,1,0)$ & 0 & $(0,1,0)$ & 0 \\
\hline 40 & ECYAP & $(0,1,1)$ & 1 & $(0,1,0)$ & 0 \\
\hline 41 & EGEEN & $(0,1,0)$ & 0 & $(0,1,0)$ & 0 \\
\hline 42 & EGGUB & $(0,1,0)$ & 0 & $(1,0,0)$ & 1 \\
\hline 43 & EGPRO & $(1,1,0)$ & 1 & $(0,0,0)$ & 1 \\
\hline 44 & EGSER & $(0,1,0)$ & 0 & $(0,1,0)$ & 0 \\
\hline 45 & EMNIS & $(0,1,0)$ & 0 & $(0,1,0)$ & 0 \\
\hline 46 & EPLAS & $(0,1,0)$ & 0 & $(0,1,1)$ & 1 \\
\hline 47 & ERBOS & $(0,1,0)$ & 0 & $(0,1,0)$ & 0 \\
\hline 48 & EREGL & $(0,1,1)$ & 1 & $(0,1,0)$ & 0 \\
\hline 49 & ESEMS & $(0,1,0)$ & 0 & $(1,1,0)$ & 1 \\
\hline 50 & FENIS & $(0,1,1)$ & 1 & $(1,1,0)$ & 1 \\
\hline 51 & FMIZP & $(2,1,0)$ & 1 & $(0,0,0)$ & 1 \\
\hline 52 & FRIGO & $(0,1,0)$ & 0 & $(0,0,0)$ & 1 \\
\hline 53 & FROTO & $(0,1,0)$ & 0 & $(1,1,0)$ & 1 \\
\hline 54 & GENTS & $(0,1,0)$ & 0 & $(0,1,1)$ & 1 \\
\hline 55 & GOLTS & $(2,1,6)$ & 1 & $(0,1,0)$ & 0 \\
\hline 56 & GOODY & $(0,1,0)$ & 0 & $(0,1,0)$ & 0 \\
\hline 57 & GUBRF & $(0,1,0)$ & 0 & $(2,1,0)$ & 1 \\
\hline 58 & HEKTS & $(2,1,0)$ & 1 & $(0,0,4)$ & 1 \\
\hline 59 & HURGZ & $(0,1,1)$ & 1 & $(0,1,0)$ & 0 \\
\hline 60 & IZMDC & $(0,1,0)$ & 0 & $(1,0,0)$ & 1 \\
\hline 61 & IZOCM & $(0,1,0)$ & 0 & $(0,1,1)$ & 1 \\
\hline 62 & KAPLM & $(0,1,0)$ & 0 & $(0,1,0)$ & 0 \\
\hline 63 & KARTN & $(0,1,0)$ & 0 & $(0,1,0)$ & 0 \\
\hline 64 & KENT & $(0,1,0)$ & 0 & $(0,0,4)$ & 1 \\
\hline 65 & KERVT & $(0,1,0)$ & 0 & $(4,1,0)$ & 1 \\
\hline 66 & KNFRT & $(3,1,1)$ & 1 & $(3,0,0)$ & 1 \\
\hline 67 & KONYA & $(3,1,1)$ & 1 & $(0,0,1)$ & 1 \\
\hline 68 & KORDS & $(0,1,0)$ & 0 & $(0,1,0)$ & 0 \\
\hline
\end{tabular}

\begin{tabular}{|r|l|c|c|c|c|}
\hline \multirow{2}{*}{$\#$} & \multirow{2}{*}{ Firm } & \multicolumn{2}{|c|}{$\mathbf{1 9 9 6 -}$} & \multicolumn{2}{|c|}{$\mathbf{2 0 0 5}-$} \\
\cline { 3 - 6 } & & Model & $\mathrm{c}$ & Model & $\mathrm{c}$ \\
\hline 69 & KRTEK & $(0,1,0)$ & 0 & $(0,0,2)$ & 1 \\
\hline 70 & KUTPO & $(0,1,0)$ & 0 & $(0,1,0)$ & 0 \\
\hline 71 & LUKSK & $(0,1,1)$ & 1 & $(2,1,0)$ & 1 \\
\hline 72 & MAKTK & $(0,1,0)$ & 0 & $(0,2,1)$ & 1 \\
\hline 73 & MERKO & $(4,1,0)$ & 1 & $(0,0,0)$ & 1 \\
\hline 74 & MRDIN & $(0,1,0)$ & 0 & $(0,1,0)$ & 0 \\
\hline 75 & MUTLU & $(0,1,0)$ & 0 & $(0,1,0)$ & 0 \\
\hline 76 & OLMIP & $(0,1,0)$ & 0 & $(0,1,0)$ & 0 \\
\hline 77 & OTKAR & $(0,1,0)$ & 0 & $(1,1,0)$ & 1 \\
\hline 78 & PARSN & $(0,1,0)$ & 0 & $(1,1,0)$ & 1 \\
\hline 79 & PETKM & $(0,1,0)$ & 0 & $(0,1,0)$ & 0 \\
\hline 80 & PIMAS & $(1,1,0)$ & 1 & $(0,1,0)$ & 0 \\
\hline 81 & PINSU & $(2,1,0)$ & 1 & $(2,1,0)$ & 1 \\
\hline 82 & PNSUT & $(0,1,1)$ & 1 & $(0,1,0)$ & 0 \\
\hline 83 & PRKAB & $(0,1,0)$ & 0 & $(0,1,0)$ & 0 \\
\hline 84 & PTOFS & $(0,1,0)$ & 0 & $(0,1,0)$ & 0 \\
\hline 85 & SARKY & $(0,1,1)$ & 1 & $(1,0,0)$ & 1 \\
\hline 86 & SASA & $(0,1,1)$ & 1 & $(0,1,0)$ & 0 \\
\hline 87 & SKTAS & $(0,1,0)$ & 0 & $(0,1,0)$ & 0 \\
\hline 88 & SNPAM & $(0,1,0)$ & 0 & $(0,1,0)$ & 0 \\
\hline 89 & TATGD & $(3,1,1)$ & 1 & $(3,1,0)$ & 1 \\
\hline 90 & TBORG & $(2,1,0)$ & 1 & $(0,1,0)$ & 0 \\
\hline 91 & TIRE & $(0,1,0)$ & 0 & $(0,1,0)$ & 0 \\
\hline 92 & TOASO & $(0,1,6)$ & 1 & $(0,1,0)$ & 0 \\
\hline 93 & TRKCM & $(0,1,0)$ & 0 & $(0,1,0)$ & 0 \\
\hline 94 & TUKAS & $(0,1,0)$ & 0 & $(0,1,0)$ & 0 \\
\hline 95 & TUPRS & $(2,1,0)$ & 1 & $(0,0,4)$ & 1 \\
\hline 96 & ULKER & $(0,1,0)$ & 0 & $(1,0,0)$ & 1 \\
\hline 97 & UNYEC & $(0,1,0)$ & 0 & $(0,1,0)$ & 0 \\
\hline 98 & USAK & $(0,1,0)$ & 0 & $(0,1,0)$ & 0 \\
\hline 99 & UZEL & $(0,1,0)$ & 0 & $(0,1,0)$ & 0 \\
\hline 100 & VKING & $(0,1,0)$ & 0 & $(1,0,0)$ & 1 \\
\hline 101 & YATAS & $(0,1,0)$ & 0 & $(1,1,0)$ & 1 \\
\hline 102 & YUNSA & $(0,2,0)$ & 1 & $(1,1,0)$ & 1 \\
\hline
\end{tabular}


To test the significance of change after the adoption of IFRS, the proportion test is applied, using the following formula:

$$
\begin{aligned}
& z=\frac{\left(\widehat{p_{1}}-\widehat{p_{2}}\right)-0}{\sqrt{\hat{p}(1-\hat{p})\left(\frac{1}{n_{1}}+\frac{1}{n_{2}}\right)}} \\
& \text { Where: } \hat{p}=\frac{y_{1}+y_{2}}{n_{1}+n_{2}}
\end{aligned}
$$

Table 2: Comparison between pre adoption and post adoption periods using ARIMA (Inventory)

\begin{tabular}{ccccc}
\hline & \multicolumn{3}{c}{ Post adoption } & \multirow{2}{*}{ Total } \\
\cline { 2 - 5 } & & Predictability & No Predictability & \\
\hline \multirow{2}{*}{ Pre adoption } & Predictability & 21 & 13 & 34 \\
\cline { 2 - 5 } & No Predictability & 27 & 41 & 68 \\
\hline \multirow{2}{*}{ Total } & 48 & 54 & 102 \\
\hline
\end{tabular}

The results are as follows:

$\begin{array}{lll}\text { Sample } & X \quad N & \text { Sample p } \\ 1 & 34102 & 0.333333 \\ 2 & 48102 & 0.470588\end{array}$

Difference $=p(1)-p(2)$

Estimate for difference: -0.137255

95\% Cl for difference: $(-0.270491,-0.00401845)$

Test for difference $=0(v s \neq 0): Z=-2.02 \quad P$-Value $=0.043$

These results show a $Z$ value greater than 1.96, which implies that the change is significant, while the negative sign implies that the significance is in favor of the post adoption period.

In addition, the MAPE (Mean Absolute Percentage of Error) values, which provide a percentage measure of error for prediction, are compared between the pre and post IFRS adoption periods. The following table presents these comparisons.

A total of 21 firms have predictable inventory information in the pre and post adoption periods. As shown in the previous table, MAPE values for 10 out of the 21 firms improved in the post IFRS adoption period. The average MAPE in the pre and post adoption periods are 19.75 and 24.99 respectively. This shows that there is no difference after the adoption of IFRS.

\section{Measuring predictability of accounts receivable}

The results of the ARIMA model, in regard to Accounts receivable information, is shown in the following table; (1) is used to present firms with predictable Accounts receivable information and (0) is used to present firms with no predictable Accounts receivable information.

The Accounts receivable data series consist of 98 firms with complete data for analysis. In the pre adoption period, 60.20 percent of the total sample of firms has Accounts receivable information that could not be used to make future predictions. While as, 39.80 percent of the total firms has Accounts receivable information that could be used to make future predictions. On the other hand, the post adoption period results show that the percentage number of firms with Accounts receivable information that could be used to make future predictions increases to 60.20 percent, leaving 39.80 percent of total firms without an ability to predict future Accounts receivable information. According to the results, 20 firms are shown to have gained an ability to predict Accounts receivable information after the adoption of IFRS. This number could be explained as follows; 14 firms lost their predictability while 34 firms gained predictability after the adoption of IFRS. 
Table 3: MAPE Value (Inventory)

\begin{tabular}{|c|c|c|c|c|c|c|c|c|c|c|c|}
\hline \# & company & $\begin{array}{l}\text { MAPE- } \\
\text { pre }\end{array}$ & $\begin{array}{c}\text { MAPE- } \\
\text { post }\end{array}$ & \# & company & $\begin{array}{c}\text { MAPE- } \\
\text { pre }\end{array}$ & \begin{tabular}{|c|} 
MAPE- \\
psot
\end{tabular} & \# & company & $\begin{array}{c}\text { MAPE- } \\
\text { pre }\end{array}$ & $\begin{array}{c}\text { MAPE- } \\
\text { post }\end{array}$ \\
\hline 1 & ADANA & 19.542 & 10.258 & 35 & DGZTE & 24.309 & 20.318 & 69 & KRTEK & 12.664 & 13.092 \\
\hline 2 & ADBGR & 9.542 & 10.258 & 36 & DITAS & 12.005 & 9.766 & 70 & KUTPO & 13.177 & 4.760 \\
\hline 3 & ADEL & 7.126 & 9.550 & 37 & DOGUB & 11.651 & 10.225 & 71 & LUKSK & 10.792 & 11.309 \\
\hline 4 & ADNAC & 19.542 & 10.258 & 38 & DURDO & 16.495 & 15.812 & 72 & MAKTK & 77.364 & 10.188 \\
\hline 5 & AFYON & 21.453 & 19.123 & 39 & DYOBY & 25.420 & 12.643 & 73 & MALAT & 11.722 & 6.076 \\
\hline 6 & AKCNS & 6.632 & 9.113 & 40 & ECYAP & 13.096 & 7.032 & 74 & MERKO & 19.909 & 81.392 \\
\hline 7 & AKSA & 17.187 & 13.441 & 41 & EGEEN & 16.623 & 12.514 & 75 & MRDIN & 25.577 & 17.761 \\
\hline 8 & ALCAR & 10.285 & 9.962 & 42 & EGGUB & 49.760 & 45.572 & 76 & MUTLU & 20.217 & 10.682 \\
\hline 9 & ANACM & .688 & 13.353 & 43 & EGPRO & 19.558 & 31.550 & 77 & OLMIP & 26.900 & 11.337 \\
\hline 10 & ARCLK & 18.333 & 7.826 & 44 & EGSER & 11.818 & 8.507 & 78 & OTKAR & 34.666 & 17.915 \\
\hline 11 & ASLAN & 17.356 & 21.368 & 45 & EMNIS & 18.607 & 14.990 & 79 & PARSN & 10.687 & 8.256 \\
\hline 12 & ASUZU & 17.584 & 15.788 & 46 & EPLAS & 15.241 & 11.757 & 80 & PETKM & 22.707 & 13.902 \\
\hline 13 & ATEKS & 12.099 & 7.342 & 47 & ERBOS & 18.069 & 16.751 & 81 & PIMAS & 21.714 & 13.874 \\
\hline 14 & AYGAZ & 31.441 & 15.166 & 48 & EREGL & 19.850 & 11.464 & 82 & PINSU & 16.115 & 7.012 \\
\hline 15 & BAGFS & 39.985 & 36.544 & 49 & ESEMS & 12.837 & 22.279 & 83 & PNSUT & 21.328 & 13.076 \\
\hline 16 & BANVT & 17.218 & 15.152 & 50 & FENIS & 24.062 & 20.685 & 84 & PRKAB & 21.437 & 12.129 \\
\hline 17 & BFREN & 15.718 & 17.077 & 51 & FMIZP & 16.250 & 19.457 & 85 & PTOFS & 16.257 & 11.254 \\
\hline 18 & BOLUC & 21.444 & 17.119 & 52 & FRIGO & 12.418 & 12.205 & 86 & SARKY & 30.527 & 22.428 \\
\hline 19 & BOSSA & 8.182 & 7.494 & 53 & FROTO & 21.270 & 14.578 & 87 & SASA & 11.382 & 14.653 \\
\hline 20 & BRISA & 18.217 & 10.286 & 54 & GENTS & 11.317 & 7.352 & 88 & SKTAS & 10.009 & 7.145 \\
\hline 21 & BRSAN & 18.295 & 17.544 & 55 & GOLTS & 19.772 & 14.673 & 89 & SNPAM & 16.277 & 19.984 \\
\hline 22 & BTCIM & 3.925 & 7.480 & 56 & GOODY & 18.152 & 14.040 & 90 & TATGD & 16.520 & 11.215 \\
\hline 23 & BUCIM & 23.457 & 7.850 & 57 & GUBRF & 46.979 & 24.389 & 91 & TBORG & 17.289 & 12.641 \\
\hline 24 & BURCE & 15.838 & 6.779 & 58 & HEKTS & 21.851 & 27.719 & 92 & TIRE & 13.219 & 12.653 \\
\hline 25 & CELHA & 18.753 & 25.735 & 59 & HURGZ & 24.650 & 7.888 & 93 & TOASO & 19.935 & 10.469 \\
\hline 26 & CEMTS & 17.288 & 11.634 & 60 & IZMDC & 42.284 & 47.625 & 94 & TRKCM & 14.639 & 7.318 \\
\hline 27 & CIMSA & 14.829 & 9.715 & 61 & IZOCM & 18.464 & 16.870 & 95 & TUKAS & 17.344 & 15.041 \\
\hline 28 & CMENT & 14.640 & 11.943 & 62 & KAPLM & 14.866 & 12.354 & 96 & TUPRS & 26.517 & 30.416 \\
\hline 29 & COMDO & 14.697 & 12.404 & 63 & KARTN & 12.986 & 6.276 & 97 & ULKER & 28.843 & 21.462 \\
\hline 30 & DARDL & 30.449 & 95.667 & 64 & KENT & 18.521 & 13.067 & 98 & UNYEC & 105.845 & 20.792 \\
\hline 31 & DENCM & 20.513 & 3.259 & 65 & KERVT & 13.350 & 10.118 & 99 & USAK & 22.832 & 13.412 \\
\hline 32 & DERIM & 20.746 & 24.543 & 66 & KNFRT & 28.633 & 23.453 & 100 & UZEL & 17.083 & 9.690 \\
\hline 33 & DEVA & 16.092 & 9.895 & 67 & KONYA & 14.296 & 14.610 & 101 & VKING & 24.163 & 11.560 \\
\hline \multirow[t]{2}{*}{34} & DGKLB & 11.361 & 14.548 & 68 & KORDS & 10.713 & 9.981 & 102 & YATAS & 15.450 & 16.030 \\
\hline & & & & & & & & 103 & YUNSA & 14.156 & 6.552 \\
\hline
\end{tabular}

To test the significance of change after the adoption of IFRS, the proportion test is applied and the results are as follows:

$$
\begin{array}{lll}
\text { Sample } & X \mathrm{~N} & \text { Sample p } \\
1 & 3998 & 0.397959 \\
2 & 5998 & 0.602041
\end{array}
$$

Difference $=p(1)-p(2)$

Estimate for difference: -0.204082

95\% Cl for difference: $(-0.341133,-0.0670306)$

Test for difference $=0(v s \neq 0): Z=-2.92 \quad P$-Value $=0.004$ 
Table 4: ARIMA Model (Accounts Recivable)

\begin{tabular}{|c|c|c|c|c|c|c|c|c|c|c|c|c|c|c|c|c|c|}
\hline \multirow{2}{*}{ \# } & \multirow{2}{*}{ Firm } & \multicolumn{2}{|l|}{ 1996- } & \multicolumn{2}{|c|}{ 2005- } & \multirow{2}{*}{ \# } & \multirow{2}{*}{ Firm } & \multicolumn{2}{|l|}{ 1996- } & \multicolumn{2}{|c|}{ 2005- } & \multirow{2}{*}{ \# } & \multirow{2}{*}{ Firm } & \multicolumn{2}{|l|}{ 1996- } & \multicolumn{2}{|l|}{ 2005- } \\
\hline & & Model & $\mathrm{c}$ & Model & c & & & Model & c & Model & c & & & Model & & Model & \\
\hline 1 & ADANA & $(0,1,0)$ & 0 & $(2,1,0)$ & 1 & 34 & DOGUB & $(0,1,0)$ & 0 & $(0,0,1)$ & 1 & 67 & MAKTK & $(0,1,0)$ & & $(0,1,0)$ & \\
\hline 2 & ADBGR & $(0,1,0)$ & 0 & $(2,1,0)$ & 1 & 35 & DURDO & $(0,1,0)$ & 0 & $(0,1,4)$ & 1 & 68 & MERKO & $(1,1,0)$ & & $(0,0,0)$ & 1 \\
\hline 3 & ADEL & $(3,1,0)$ & 1 & $(3,1,0)$ & 1 & 36 & DYOBY & $(0,1,0)$ & 0 & $(3,1,0)$ & 1 & 69 & MRDIN & $(0,1,2)$ & & $(2,1,0)$ & 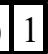 \\
\hline 4 & ADNAC & $(0,1,0)$ & 0 & $(2,1,0)$ & 1 & 37 & ECYAP & $(0,1,0)$ & 0 & $(0,1,0)$ & 0 & 70 & MRSHL & $(0,1,4)$ & & $(2,0,1)$ & 1 \\
\hline 5 & AFYON & $(3,0,0)$ & 1 & $(3,0,0)$ & 1 & 38 & EGEEN & $(0,1,0)$ & 0 & $(1,1,0)$ & 1 & 71 & MUTLU & $(2,1,0)$ & & $(0,1,0)$ & 0 \\
\hline 6 & AKCNS & $(2,1,0)$ & 1 & $(3,1,0)$ & 1 & 39 & EGGUB & $(0,1,1)$ & 1 & $(3,1,0)$ & 1 & 72 & OLMIP & $(0,1,0)$ & & $(0,1,0)$ & 0 \\
\hline 7 & AKSA & $(0,1,0)$ & 0 & $(0,0,1)$ & 1 & 40 & EGPRO & $(0,2,1)$ & 1 & $(0,1,0)$ & 0 & 73 & $\mathrm{OTI}$ & $(0,1,1)$ & & $(0,1,0)$ & 0 \\
\hline 8 & ANACM & $(3,1,1)$ & 1 & $(2,1,0)$ & 1 & 41 & EMNIS & $(0,1,1)$ & 1 & $(3,1,0)$ & 1 & 74 & PETKM & $(0,1,0)$ & 0 & $(0,1,0)$ & 0 \\
\hline 9 & ARCLK & $(0,1,0)$ & 0 & $(2,1,0)$ & 1 & 42 & EREGL & $(3,1,0)$ & 1 & $(0,1,0)$ & 0 & 75 & PIMAS & $(0,1,0)$ & & $(0,1,0)$ & 0 \\
\hline 10 & ASLAN & $(0,1,0)$ & 0 & $(2,1,0)$ & 1 & 43 & ESEMS & $(1,1,0)$ & 1 & $(0,1,0)$ & 0 & 76 & PIN & $(2,1,0)$ & & $(0,1,0)$ & 0 \\
\hline 11 & ASUZU & $(0,1,0)$ & 0 & $(4,1,0)$ & 1 & 44 & FENIS & $(0,2,0)$ & 1 & $(0,1,0)$ & 0 & 77 & PNSUT & $(0,1,0)$ & 0 & $(0,1,0)$ & 0 \\
\hline 12 & ATEKS & $(0,1,0)$ & 0 & $(2,1,0)$ & 1 & 45 & FMIZP & $(2,1,0)$ & 1 & $(0,1,0)$ & 0 & 78 & PRKAB & $(0,1,0)$ & & $(0,1,0)$ & 0 \\
\hline 13 & AYGAZ & $(0,1,1)$ & 1 & $(1,0,0)$ & 1 & 46 & FRIGO & $(0,1,0)$ & 0 & $(0,0,0)$ & 1 & 79 & PTOFS & $(2,1,0)$ & & $(2,1,0)$ & 1 \\
\hline 14 & BAGFS & $(0,0,2)$ & 1 & $(3,1,0)$ & 1 & 47 & FROTO & $(0,1,0)$ & 0 & $(3,1,0)$ & 1 & 80 & SARKY & $(0,1,0)$ & & $(0,1,0)$ & 0 \\
\hline 15 & BANVT & $(0,1,0)$ & 0 & & 1 & 48 & & & 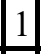 & $(0,1,0)$ & 0 & 81 & & $(0,1,0)$ & & $(0,1,0)$ & 0 \\
\hline 16 & BFREN & $(0,1,0)$ & 0 & $(1,0,0)$ & 1 & 49 & GOLTS & $(1,1,0)$ & 1 & $(0,1,0)$ & 0 & 82 & SKTAS & $(1,1,0)$ & & $(1,1,0)$ & 1 \\
\hline 17 & BOLUC & $(4,1,0)$ & 1 & $(0,1,4)$ & 1 & 50 & GOODY & $(0,1,0)$ & 0 & $(1,1,0)$ & 1 & 83 & SNPAM & $(0,1,0)$ & & $(0,1,0)$ & 0 \\
\hline 18 & BOSSA & $(0,1,1)$ & 1 & $(3,1,0)$ & 1 & 51 & GUBRF & $(1,1,2)$ & 1 & $(1,1,0)$ & 1 & 84 & TATGD & $(0,1,0)$ & & $(0,1,0)$ & 0 \\
\hline 19 & BRISA & $(0,1,2)$ & 1 & $(0,1,0)$ & 0 & 52 & HEKTS & $(4,1,0)$ & 1 & $(0,0,0)$ & 1 & 85 & TBORG & $(0,1,0)$ & & $(4,1,0)$ & 1 \\
\hline 20 & BRSAN & $(0,1,0)$ & 0 & $(1,0,0)$ & 1 & 53 & HURGZ & $(0,1,0)$ & 0 & $(1,0,0)$ & 1 & 86 & TIRE & $(0,1,0)$ & & $(0,1,0)$ & 0 \\
\hline 21 & BTCIM & $(0,1,0)$ & 0 & $(1,1,0)$ & 1 & 54 & HZNDR & $(0,1,0)$ & 0 & $(0,1,0)$ & 0 & 87 & & $(0,1,0)$ & $\theta$ & $(2,1,0)$ & 1 \\
\hline 22 & BUCIM & $(0,1,0)$ & 0 & $(1,0,0)$ & 1 & 55 & IZMDC & $(0,1,0)$ & 0 & $(1,0,0)$ & 1 & 88 & TRCAS & $(0,1,0)$ & & $(0,1,0)$ & 0 \\
\hline 23 & BURCE & $(0,1,0)$ & 0 & $(0,0,2)$ & 1 & 56 & IZOCM & $(4,1,0)$ & 1 & $(4,1,0)$ & 1 & 89 & TRKCM & $(2,1,0)$ & & $(0,1,0)$ & 0 \\
\hline 24 & CELHA & $(0,1,0)$ & 0 & $(0,1,0)$ & 0 & 57 & KAPLM & $(0,1,0)$ & 0 & $(0,1,1)$ & 1 & 90 & TUDDF & $(0,1,0)$ & & $(0,0,1)$ & 1 \\
\hline 25 & CEMTS & $(0,1,0)$ & 0 & $(0,1,0)$ & 0 & 58 & KARTN & $(0,1,0)$ & 0 & $(0,1,0)$ & 0 & 91 & TUKAS & $(3,1,0)$ & & $(1,0,0)$ & 1 \\
\hline 26 & CIMSA & $(2,1,2)$ & 1 & $(0,1,1)$ & 1 & 59 & KENT & $(0,1,0)$ & 0 & $(0,0,1)$ & 1 & 92 & TUPRS & $(0,1,1)$ & & $(0,1,0)$ & 0 \\
\hline 27 & CMENT & $(0,1,0)$ & 0 & $(4,1,0)$ & 1 & 60 & KERVT & $(0,1,0)$ & 0 & $(0,1,0)$ & 0 & 93 & ULKER & $(0,1,0)$ & & $(1,1,1)$ & 1 \\
\hline 28 & DENCM & $(0,1,0)$ & 0 & $(0,1,1)$ & & 61 & KNFRT & $(1,1,0)$ & & $(2,1,0)$ & 1 & 94 & UNYEC & $(4,1,0)$ & & $(0,1,4)$ & 1 \\
\hline 29 & DERIM & $(1,1,0)$ & 1 & $(0,1,1)$ & & 62 & KONYA & $(2,1,0)$ & 1 & $(0,1,4)$ & 1 & 95 & USAK & $(0,1,0)$ & & $(0,1,0)$ & 0 \\
\hline 30 & DEVA & $(0,1,0)$ & 0 & $(0,1,0)$ & 0 & 63 & KORDS & $(0,1,0)$ & 0 & $(1,0,0)$ & 1 & 96 & VESTL & $(0,1,0)$ & & $(0,1,0)$ & 0 \\
\hline 31 & DGKLB & $(0,1,0)$ & 0 & $(0,1,0)$ & 0 & 64 & KRTEK & $(0,1,0)$ & 0 & $(0,1,2)$ & 11 & 97 & VKING & $(0,1,0)$ & & $(0,0,0)$ & 1 \\
\hline 32 & DGZTE & $(0,1,0)$ & 0 & $(0,1,0)$ & 0 & 65 & KUTPO & $(0,1,0)$ & 0 & $(0,1,0)$ & 0 & 98 & YATAS & $(0,1,0)$ & & $(0,1,0)$ & 0 \\
\hline 33 & DITAS & $(1,1,0)$ & 11 & $(3,1,1)$ & 11 & 66 & LUKSK & $(2,1,0)$ & 11 & $(0,1,0)$ & 10 & & & & & & \\
\hline
\end{tabular}

These results show a $\mathrm{Z}$ value greater than 1.96, which implies that the change is significant, while the negative sign implies that the significance is in favor of the post adoption period.

In addition, the MAPE values are compared between the pre and post IFRS adoption periods. The following table presents these comparisons
Table 5: Comparison between pre adoption and post adoption periods using ARIMA (Accounts receivable)

\begin{tabular}{ccccc}
\hline & \multicolumn{3}{c}{ Post adoption } & Total \\
\cline { 2 - 5 } Pre & Predictability & 25 & 14 & 39 \\
\cline { 2 - 5 } adoption & No predictability & 34 & 25 & 59 \\
\hline Total & 59 & 39 & 98 \\
\hline
\end{tabular}


Table 6: MAPE Value (Accounts Receivaable)

\begin{tabular}{|c|c|c|c|c|c|c|c|c|c|c|c|}
\hline \# & Company & $\begin{array}{l}\text { MAPE- } \\
\text { pre }\end{array}$ & $\begin{array}{c}\text { MAPE- } \\
\text { post }\end{array}$ & \# & Company & MAPE-pre & $\begin{array}{c}\text { MAPE- } \\
\text { post }\end{array}$ & \# & \begin{tabular}{|l|}
$\begin{array}{l}\text { Compan } \\
\mathrm{y}\end{array}$ \\
\end{tabular} & $\begin{array}{c}\text { MAPE- } \\
\text { pre }\end{array}$ & $\begin{array}{c}\text { MAPE- } \\
\text { post }\end{array}$ \\
\hline 1 & ADANA & 24.942 & 12.510 & 34 & DOGUB & 66.172 & 43.449 & 67 & MAKTK & 29.016 & 34.539 \\
\hline 2 & $\overline{\mathrm{DBGR}}$ & .942 & 12.510 & 35 & DURDO & 21.716 & 12.533 & 68 & MALAT & 92.193 & 7.571 \\
\hline 3 & ADEL & 36.669 & 67.711 & 36 & DYOBY & 24.825 & 19.186 & 69 & MERKO & 30.730 & 22.280 \\
\hline 4 & ADNAC & 24.942 & 12.510 & 37 & ECYAP & 15.412 & 86.492 & 70 & MRDIN & 50.201 & 9.892 \\
\hline 5 & AFYON & 39.702 & 22.225 & 38 & EGEEN & 33.655 & 14.792 & 71 & MRSHL & 30.772 & 26.488 \\
\hline 6 & AKCNS & 23.017 & 9.656 & 39 & EGGUB & 210.303 & 86.079 & 72 & MUTLU & 15.267 & 15.273 \\
\hline 7 & AKSA & 12.015 & 8.526 & 40 & EGPRO & 19.701 & 8.695 & 73 & OLMIP & 13.345 & 4.535 \\
\hline 8 & ANACM & 23.179 & 15.664 & 41 & EMNIS & 46.787 & 21.773 & 74 & OTKAR & 34.793 & 16.284 \\
\hline 9 & ARCLK & 38.225 & 7.523 & 42 & EREGL & 17.119 & 9.777 & 75 & PETKM & 14.391 & 11.391 \\
\hline 10 & ASLAN & 26.688 & 9.771 & 43 & ESEMS & 15.806 & 31.671 & 76 & PIMAS & 21.270 & 10.489 \\
\hline 11 & ASUZU & 33.043 & 20.220 & 44 & FENIS & & 75.194 & 77 & PINSU & 153.058 & 125.235 \\
\hline 12 & ATEKS & 9.923 & 15.265 & 45 & FMIZP & 30.510 & 90.249 & 78 & PNSUT & 29.956 & 29.150 \\
\hline 13 & AYGAZ & 17.727 & 14.256 & 46 & FRIGO & & 23.946 & 79 & PRKAB & 16.478 & 10.935 \\
\hline 14 & BAGFS & 636.139 & 63.118 & 47 & FROTO & 24.2 & 13.507 & 80 & PTOFS & 47.621 & 11.423 \\
\hline 15 & BANVT & 23.956 & 13.719 & 48 & GENTS & 25.066 & 11.581 & 81 & SARKY & 12.242 & 14.053 \\
\hline 16 & BFREN & 24. & 21.996 & 49 & GOLTS & & 18.877 & 82 & SASA & 18.482 & 17.073 \\
\hline 17 & BOLUC & 13.445 & 14.913 & 50 & GOODY & 12.975 & 16.163 & 83 & SKTAS & 11.566 & 15.584 \\
\hline 18 & BOSSA & 15.523 & 9.506 & 51 & GUBRF & 193.457 & 39.163 & 84 & SNPAM & 19.701 & 17.835 \\
\hline 19 & BRISA & 13.344 & 11.468 & 52 & HEKTS & 20.1 & 48.677 & 85 & TATGD & 56.874 & 46.508 \\
\hline 20 & BRSAN & 9.422 & 26.401 & 53 & HURGZ & 16.004 & 9.851 & 86 & TBORG & 27.384 & 10.348 \\
\hline 21 & BTCIM & & 9.863 & 54 & HZNDR & & 17.951 & 87 & TIRE & 12.641 & 7.339 \\
\hline 22 & $B \cup C I M$ & 20.810 & 14.714 & 55 & IZMDC & 140.686 & 131.609 & 88 & TOASO & 28.720 & 20.668 \\
\hline 23 & BURCE & 23.168 & 31.570 & 56 & IZOCM & 17.762 & 5.272 & 89 & TRCAS & 32.009 & 124.524 \\
\hline 24 & CELHA & 12.920 & 10.977 & 57 & KAPLM & 321 & 13.255 & 90 & TRKCM & 20.355 & 8.632 \\
\hline 25 & CEMTS & 24.720 & 15.197 & 58 & KARTN & 15.340 & 6.946 & 91 & TUDDF & 12.428 & 11.909 \\
\hline 26 & CIMSA & 12.324 & 1515.971 & 59 & KENT & 26.472 & 40.017 & 92 & TUKAS & 60.895 & 14.038 \\
\hline 27 & CMENT & 19.392 & 7.913 & 60 & KERVT & 19.659 & 27.679 & 93 & TUPRS & 60.855 & 23.704 \\
\hline 28 & DENCM & 1659.885 & 748.365 & 61 & KNFRT & 70.925 & 38.996 & 94 & ULKER & 32.497 & 16.024 \\
\hline 29 & DERIM & 60.972 & $25 \mathrm{M}$ & 62 & KONYA & 23.662 & 13.957 & 95 & UNYEC & 21.116 & 8.513 \\
\hline 30 & DEVA & 15.508 & 11.585 & 63 & KORDS & 17.944 & 13.913 & 96 & USAK & 24.326 & 19.009 \\
\hline 31 & DGKLB & 17.209 & 24.591 & 64 & KRTEK & 15.798 & 7.309 & 97 & VESTL & 12.570 & 8.056 \\
\hline 32 & DGZTE & 25.539 & 10.871 & 65 & KUTPO & 19.846 & 13.014 & 98 & VKING & 23.699 & 12.198 \\
\hline 33 & DITAS & 28.951 & 9.682 & 66 & LUKSK & 25.831 & 19.862 & 99 & YATAS & 15.588 & 11.189 \\
\hline
\end{tabular}

A total of 25 firms have predictable Accounts receivable information in the pre and post adoption periods. As shown in the previous table, MAPE values for 6 out of the 25 firms improved in the post IFRS adoption period.

\section{Conclusion}

According to the results of applying the ARIMA model on the chosen accounting elements, it is concluded that 14 and 20 firms had their predictability increase for Inventory and Accounts receivable elements respectively after the adoption of IFRS. When these results are examined for significance using the Proportional test, the predictability of Inventory and Accounts receivable elements is deemed significant. In addition, the MAPE of the model's ability of estimation show that the accuracy of estimation either decreased or stayed the same after the adoption of IFRS. 


\section{References}

Alali, F. A. \& Foote, P. S. (2012). «The Value Relevance of International Financial Reporting Standards: Empirical Evidence in an Emerging Market» The International Journal of Accounting, 47 (1), 85-108. https://doi.org/10.1016/j.intacc.2011.12.005

- $\quad$ Alford, A.; Jones, J.; Leftwich, R. \& Zmijewski, M. (1993). «The Relative Informativeness of Accounting Disclosures in Different Countries», Journal of Accounting Research, 183-223.

- $\quad$ Ali, A. \& Hwang, L. S. (2000). «Country-specific Factors Related to Financial Reporting and the Value Relevance of Accounting Data», Journal of Accounting Research, 1-21.

- $\quad$ Anandarajan, A. \& Hasan, I. (2010). «Value Relevance of Earnings: Evidence from Middle Eastern and North African Countries», Advances in Accounting, 26 (2), 270-279. https://doi.org/10.1016/j.adiac.2010.08.007

- $\quad$ Ashbaugh, H. \& Pincus, M. (2001). «Domestic Accounting Standards, International Accounting Standards, and the Predictability of Earnings», Journal of Accounting Research, 39 (3), 417-434.

- $\quad$ Ashraf, C. K. (2012). «The Relationship between Working Capital Efficiency and Profitability», Advances In Management, Vol. 5, 12.

- Bahadir, O. \& Tolga, B. (2013). «Accounting Policy Options under IFRS: Evidence from Turkey», Journal of Accounting and Management Information Systems, 12 (3), 388-404.

- $\quad$ Ball, R. \& Brown, P. (1968). «An Empirical Evaluation of Accounting Income Numbers», Journal of Accounting Research, 6 (2), 159. https://doi.org/10.2307/2490232

- $\quad$ Ball, R. Kothari, S. P. \& Robin, A. (2000). «The Effect of International Institutional Factors on Properties of Accounting Earnings», Journal of Accounting and Economics, 29 (1), 1-51.

- $\quad$ Ball, R. Robin, A. \& Wu, J. S. (2003). «Incentives Versus Standards: Properties of Accounting Income in Four East Asian Countries», Journal of Accounting and Economics, 36 (1-3), 235-270. https://doi. org/10.1016/j.jacceco.2003.10.003

- $\quad$ Ballou, D. P. \& Pazer, H. L. (1985). «Modeling Data and Process Quality in Multi-input, Multi-output Information Systems», Management Science, 31 (2), 150-162.

- $\quad$ Bao, B. \& Chow, L. (1999). «The Usefulness of Earnings and Book Value for Equity Valuation in Emerging Capital Markets: Evidence from Listed Companies in the People's Republic of China», Journal of International Financial Management \& Accounting, 10 (2), 85-104.

- $\quad$ Barth, M. E., Landsman, W. R., \& Lang, M. H. (2008). «International Accounting Standards and Accounting Quality», Journal of Accounting Research, 46 (3), 467-498. https://doi.org/10.1111/j.1475679X.2008.00287.x

- $\quad$ Barth, M. E.; Beaver, W. H. \& Landsman, W. R. (2001). «The Relevance of the Value Relevance Literature for Financial Accounting Standard Setting: Another View», Journal of Accounting and Economics, 31 (1), $77-$ 104.

- $\quad$ Barth, M. E.; Landsman, W.; Lang, M., Williams, C. (2006). «Accounting Quality: International Accounting Standards and US GAAP», Manuscript, Stanford University. Retrieved from http://b_sundari.staff.gunadarma.ac.id/Downloads/files/29750/JURNAL-7.pdf

- $\quad$ Basu, N. \& Wang, X. (2011). «Evidence on the Relation between Inventory Changes, Earnings and Firm Value», The International Journal of Business and Finance Research, 5 (3), 1-14.

- Basu, S. (1997). «The Conservatism Principle and the Asymmetric Timeliness of Earnings», Journal of Accounting and Economics, 24, 3-37.

- Beaver, W. H. (1968). «The Information Content of Annual Earnings Announcements», Journal of Accounting Research, 6, 67. https://doi.org/10.2307/2490070 
Biddle, G. C. (1980). «Accounting Methods and Management Decisions: The Case of Inventory Costing and Inventory Policy", Journal of Accounting Research, 18, 235-280.

- Biddle, G. C. (1988). «Discussion of «Inventory Accounting and Earnings/ Price Ratios: A Puzzle», Contemporary Accounting Research, 5 (1), 389-396.

- $\quad$ Bougheas, S.; Mateut, S. \& Mizen, P. (2009). Corporate Trade Credit and Inventories: New Evidence of a Trade-off from Accounts Payable and Receivable», Journal of Banking \& Finance, 33 (2), 300-307. https://doi.org/10.1016/j.jbankfin.2008.07.019

- $\quad$ Bovee, M.; Srivastava, R. P. \& Mak, B. (2003). A Conceptual Framework and Belief-function Approach to Assessing Overall Information Quality», International Journal of Intelligent Systems, 18 (1), 51-74. https://doi.org/10.1002/int.10074

- $\quad$ Chen, H.; Tang, Q.; liang, Y. \& Lin, Z. (2010). «The Role of International Financial Reporting Standards in Accounting Quality: Evidence from the European Union», Journal of International Financial Management \& Accounting, 21 (3), 220-278.

- $\quad$ Christodoulos, C.; Michalakelis, C. \& Varoutas, D. (2010). «Forecasting with Limited Data: Combining ARIMA and Diffusion Models», Technological Forecasting and Social Change, 77 (4), 558-565.

- $\quad$ Clarkson, P.; Hanna, J. D.; Richardson, G. D. \& Thompson, R. (2011). «The Impact of IFRS Adoption on the Value Relevance of Book Value and Earnings», Journal of Contemporary Accounting \& Economics, 7 (1), 1-17. https://doi.org/10.1016/j.jcae.2011.03.001

- $\quad$ Cook, K.; Huston, G. \& Kinney, M. (2011). «Managing Earnings by Manipulating Production: The Effects of Cost Structure and Inventory Valuation Method», Available at SSRN 997437. Retrieved from http:// papers.ssrn.com/sol3/papers.cfm2abstract_id=997437

- $\quad$ Corina, M. \& Nicolae, M. (2012). «Quality Of Accounting Information to Optimize the Decisional Process», Annals of Faculty of Economics, 694-699.

- $\quad$ Dechow, P. M. \& Dichev, I. D. (2002). The Quality of Accruals and Earnings: The Role of Accrual Astimation errors. The Accounting Review, 77(s-1), 35-59.

- Dechow, P. M. (1994). Accounting Earnings and Cash Flows as Measures of Firm Performance: The Role of Accounting Accruals. Journal of Accounting and Economics, 18 (1), 3-42.

- DeFond, M. L. \& Jiambalvo, J. (1994). «Debt Covenant Violation and Manipulation of Accruals», Journal of Accounting and Economics, 17 (1), 145-176.

- De Gooijer, J. G. \& Hyndman, R. J. (2006). «25 Years of Time Series Forecasting», International Journal of Forecasting, 22 (3), 443-473. https://doi.org/10.1016/j.ijforecast.2006.01.001

- Djatej, A., Gao, G., Sarikas, R. H. S., \& Senteney, D. L. (2011). «Eastern and Western European firms public and Private Information Quality: The Comparative Impact of Degree of Implementation of IFRS», Emerging Markets Review, 12 (2),111-129. https://doi.org/10.1016/j.ememar.2011.02.001

- $\quad$ Easton, P. D. \& Harris, T. S. (1991). «Earnings as an explanatory variable for returns», Journal of Accounting Research, 19-36.

- Ebaid, I. E. S. (2016). «International Accounting Standards and Accounting Quality in Code-law Countries: The Case of Egypt», Journal of Financial Regulation and Compliance, 24 (1), 41-59. https://doi. org/10.1108/JFRC-12-2011-0047

- $\quad$ Ediger, V. Ş. \& Akar, S. (2007). «ARIMA Forecasting of Primary Energy Demand by Fuel in Turkey», Energy Policy, 35(3),1701-1708. https://doi.org/10.1016/j.enpol.2006.05.009

Ely, K. \& Waymire, G. (1999). «Accounting Standard-setting Organizations and Earnings Relevance: longitudinal Evidence from NYSE Common Stocks, 1927-93», Journal of Accounting Research, 293-317. 
Eppler, M. J. \& Wittig, D. (2000). «Conceptualizing Information Quality: A Review of Information Quality Frameworks from the Last Ten Years. In: Proceedings of $5^{\text {th }}$ International Conference on Information Quality (ICIQ 2000), Cambridge, MA. Retrieved from http://mitiq.mit.edu/iciq/Documents/IQ\%20 Conference\%202000/Papers/ConceptlQaReviewoflQFramework.pdf

- Fiador, V. O. (2013). «Corporate Governance and Value Relevance of Financial Information: Evidence from the Ghana Stock Exchange», Corporate Governance, 13 (2), 208-217. https://doi. org/10.1108/14720701311316689

- Fields, T. D.; Lys, T. Z. \& Vincent, L. (2001). «Empirical Research on Accounting Choice», Journal of Accounting and Economics, 31 (1), 255-307.

- Francis, J. \& Schipper, K. (1999). «Have Financial Statements Lost Their Relevance», Journal of Accounting Research, 37 (2), 319. https://doi.org/10.2307/2491412

- Francis, J.; LaFond, R.; Olsson, P. \& Schipper, K. (2005). «The Market Pricing of Accruals Quality», Journal of Accounting and Economics, 39 (2), 295-327. https://doi.org/10.1016/j.jacceco.2004.06.003

- Francis, J.; LaFond, R.; Olsson, P. M. \& Schipper, K. (2004). «Costs of Equity and Earnings Attributes», The Accounting Review, 79 (4), 1010.

- Gafarov, T. (2009). Information filters-factors influencing on accounting information. Retrieved from http://www.konference.fbm.vutbr.cz/phd/papers/papers2009/gafarov_timur.pdf

- Ge, Y. \& Qiu, J. (2007). «Financial Development, Bank Discrimination and Trade Credit», Journal of Banking \& Finance, 31 (2), 513-530. https://doi.org/10.1016/j.jbankfin.2006.07.009

- Gupta, M.; Pevzner, M. \& Seethamraju, C. (2010). «The Implications of Absorption Cost Accounting and Production Decisions for Future Firm Performance and Valuation», Contemporary Accounting Research, 27 (3), 889-922.

- Haller, A.; Ernstberger, J. \& Froschhammer, M. (2009). «Implications of the Mandatory Transition from National GAAP to IFRS: Empirical Evidence from Germany», Advances in Accounting, 25 (2), 226-236. https://doi.org/10.1016/j.adiac.2009.08.007

- Harris, T.; Lang, M. \& Möller, H. (1994). «The Value Relevance of German Accounting Measures: An Emioirical Analaysis», Journal of Accounting Research, 32.

- Herrmann, D.; Saudagaran, S. M. \& Thomas, W. B. (2006). «The Quality of Fair Value Measures for Property, Plant, and Equipment», Accounting Forum, 30 (1), 43-59. https://doi.org/10.1016/j.accfor.2005.09.001

- $\quad$ Ho, S. L. \& Xie, M. (1998). «The Use of ARIMA Models for Reliability Forecasting and Analysis», Computers \& Industrial Engineering, 35 (1), 213-216.

- Holthausen, R. W. \& Watts, R. L. (2001). «The Relevance of the Value-relevance Literature for Financial Accounting Standard Setting», Journal of Accounting and Economics, 31 (1), 3-75.

- International Accounting Standards Board. (2010). The Conceptual Framework for Financial Reporting. Retrieved from http://eifrs.ifrs.org/eifrs/bnstandards/en/2013/conceptualframework.pdf

- Jeanjean, T. \& Stolowy, H. (2008). «Do Accounting Standards Matter: An Exploratory Analysis of Earnings Management Before and After IFRS Adoption», Journal of Accounting and Public Policy, 27 (6), 480-494. https://doi.org/10.1016/j.jaccpubpol.2008.09.008

- Joos, P. \& Lang, M. (1994). «The Effects of Accounting Diversity: Evidence from the European Union», Journal of Accounting Research, 141-168.

- Joshi, M., Yapa, P. W. S., \& Kraal, D. (2016). «IFRS Adoption in ASEAN Countries: Perceptions of Professional Accountants from Singapore, Malaysia and Indonesia», International Journal of Managerial Finance, 12 (2), 211-240. https://doi.org/10.1108/IJMF-04-2014-0040 
Karampinis, N. I. \& Hevas, D. L. (2011). «Mandating IFRS in an Unfavorable Environment: The Greek Experience», The International Journal of Accounting, 46(3), 304-332. https://doi.org/10.1016/j.intacc.2011.07.001

- Kieso, D. E.; Weygandt, J. J. \& Warfield, T. D. (2012). Intermediate Accounting. Hoboken, NJ: Wiley.

- $\quad$ Klafter, J, \& Sokolov, I. M. (2011). First Steps in Random Walks: From Tools to Applications. Oxford; New York: Oxford University Press.

- $\quad$ Kohlbeck, M. \& Warfield, T. (2010). «Accounting Standard Attributes and Accounting Quality: Discussion and Analysis», Research in Accounting Regulation, 22 (2), 59-70. https://doi.org/10.1016/j.racreg.2010.07.001

- Krishnan, G. V.; Srinidhi, B. \& Su, L. Nancy. (2008). «Inventory Policy, Accruals Quality and Information Risk», Review of Accounting Studies, 13 (2-3), 369-410. https://doi.org/10.1007/s11142-008-9067-2

- Kumar, U. \& De Ridder, K. (2010). «GARCH Modelling in Association with FFT-ARIMA to Forecast Ozone Episodes», Atmospheric Environment, 44 (34), 4252-4265. https://doi.org/10.1016/j.atmosenv.2010.06.055

- $\quad$ Lai, R. (2006). «Inventory signals», Harvard NOM Research Paper Series, (06-09). Retrieved from http://papers.ssrn.com/sol3/papers.cfm2abstract_id=723381

- $\quad$ Lawler, G. F. \& Limic. (2010). Random Walk a Modern Introduction. Cambridge; New York: Cambridge University Press. Retrieved from http://public.eblib.com/EBLPublic/PublicView.do2ptilD=534740

- Lazaridis, I. \& Tryfonidis, D. (2006). «Relationship between Working Capital Management and Profitability of Listed Companies in the Athens Stock Exchange», Journal of Financial Management and Analysis, 19 (1). Retrieved from http://papers.ssrn.com/sol3/papers.cfm2abstract_id=931591

- Lev, B. (1983). «Some Economic Determinants of Time-series Properties of Earnings», Journal of Accounting and Economics, 5, 31-48.

- Lev, B. (1989). «On the Usefulness of Earnings and Earnings Research: Lessons and Directions from Two Decades of Empirical Research», Journal of Accounting Research, 153-192.

- Mao, J. C. \& Sarndal, C. E. (1974). «Controlling Risk in Accounts Receivable Management», Journal of Business Finance \& Accounting, 1 (3), 395-403.

- Mostafa, W. (2016). «The Incremental Value Relevance of Cash Flows and Earnings Affected by Their extremity: UK Evidence», Management Research Review, 39 (7), 742-767. https://doi.org/10.1108/ MRR-03-2015-0069

- $\quad$ Mulford, C. W. \& Comiskey. (2002). The Financial Numbers Game: Detecting Creative Accounting Practices. New York: Wiley.

- Okafor, O. N.; Anderson, M. \& Warsame, H. (2016). «IFRS and Value Relevance: Evidence Based on Canadian Adoption», International Journal of Managerial Finance, 12 (2), 136-160. https://doi. org/10.1108/IJMF-02-2015-0033

- Olsson, P. (2008). «Discussion of Inventory Policy, Accruals Quality and Information Risk», Review of Accounting Studies, 13 (2-3), 411-417. https://doi.org/10.1007/s11142-008-9075-2

Ostasiewicz, W. (Ed.). (2000). Socio-economical Applications of Statistical Methods. Wrocław: Wrocław University of Economics.

- Paananen, M. \& Lin, C. (2007). «The Development of Accounting Quality of IAS and IFRS Over Time: The Case of Germany. Available at SSRN 1066604. Retrieved from http://papers.ssrn.com/sol3/papers. cfm2abstract_id=1066604

- $\quad$ Pai, P. F. \& Lin, C.S. (2005). «A Hybrid ARIMA and Support Vector Machines Model in Stock Price Forecasting», Omega,33(6), 497-505. https://doi.org/10.1016/j.omega.2004.07.024 
- Pekdemir, R. \& Türel, A. (2014). «An Attempt to understand Uompliance Degree of Implementing International Standards in Accountancy: The Turkey Experience», Academy of Accounting \& Financial Studies Journal, 18 (1). Retrieved from http://www.bsu.ase.ro/other/Paper-Auditing-Pekdemir-Gunduzay.doc

- Quantitative Micro Software (Firm). (2009). EViews. 7. 7. Irvine CA: Quantitative Micro Software.

- $\quad$ Rahman, A.; Yammeesri, J. \& Perera, H. (2010). «Financial Reporting Quality in International Settings: A Comparative Study of the USA, Japan, Thailand, France and Germany", The International Journal of Accounting, 45(1), 1-34. https://doi.org/10.1016/j.intacc.2010.01.001

- $\quad$ Rajan, R. G. \& Zingales, L. (1995). «What Do We Know about Capital Structure: Some Evidence from International Data», The Journalof Finance, 50 (5), 1421. https://doi.org/10.2307/2329322

- $\quad$ Rudnick, J. A. \& Gaspari, G. D. (2004). Elements of the Random Walk: An Introduction for Advanced Students and Researchers. Cambridge; New York: Cambridge University Press. Retrieved from http:// site.ebrary.com/id/10124710

- Sopranzetti, B. J. (1998). «The Economics of Factoring Accounts Receivable». Journal of Economics and Business, 50 (4), 339-359.

- Stvilia, B.; Gasser, L.; Twidale, M. B. \& Smith, L. C. (2007). A Framework for Information Quality Assessment», Journal of the American Society for Information Science and Technology, 58 (12), 1720-1733.

- $\quad$ Sunder, S. (1973).» Relationship between Accounting Changes and Stock Prices: Problems of Measurement and Some Empirical Evidence», Journal of Accounting Research, 1-45.

- $\quad$ The IFRS Foundation and the IASB. (2013, May 26). The Move Towards Global Standards. Retrieved from http://www.ifrs.org/Use-around-the-world/Pages/Use-around-the-world.aspx

- Thomas, J. K. \& Zhang, H. (2002). «Inventory Changes and Future Returns», Review of Accounting Studies, 7 (2-3), 163-187.

- Weiss, D.; Naik, P. A. \& Tsai, C. L. (2008). «Extracting Forward-looking Information from Security Prices: A New Approach», The Accounting Review, 83 (4), 1101-1124. https:// doi.org/10.2308/accr.2008.83.4.1101

- Wongthatsanekorn, W. (Ed.). (2010). «Study of Cash-to-Cash Cycle Management on Profitability of Private Hospital in Thailand by Regular and Panel Data Regression Analyses», In: The World Congress on Engineering and Computer Science (Vol. 2). Thailand.

- Zhang, G. P. (2003). «Time Series Forecasting Using a Hybrid ARIMA and Neural Network Model», Neurocomputing, 159-175. 